\title{
Analisis Dinamika Evakuasi pada Erupsi Merapi dengan Pendekatan System Dynamics
}

\author{
Riri Nasirly ${ }^{1}$, Budi Hartono ${ }^{2}$ \\ ${ }^{1}$ Program Studi Teknik Industri, Sekolah Tinggi Teknologi Pelalawan, \\ J1. Lintas Timur Km. 28, Simpang Beringin, Bandar Seikijang, Pelalawan, Riau \\ ${ }^{2}$ Jurusan Teknik Mesin dan Industri, Fakultas Teknik, Universitas Gadjah Mada, \\ J1. Grafika No.2,Universitas Gadjah Mada, Yogyakarta \\ Email: ririnasirly11@gmail.com, boed@gadjahmada.edu
}

\begin{abstract}
ABSTRAK
Indonesia merupakan negara yang rawan terjadi bencana. Proses evakuasi merupakan proses untuk memindahkan orang dari daerah yang terancam ke lokasi yang lebih aman dan salah satu tindakan yang paling penting untuk mengurangi resiko bencana. Dalam meningkatkan proses evakuasi, pemodelan dan simulasi dapat dilakukan untuk menambah wawasan proses evakuasi saat terjadinya bencana. Keputusan untuk melakukan evakuasi menjadi hal penting dalam perencanaan evakuasi dan modeling. Penelitian ini mengkaji dinamika evakuasi yang dimodelkan dengan system dynamics, mengetahui variabel yang mempengaruhi keputusan evakuasi berdasarkan tinjauan pustaka, serta menghasilkan skenario kebijakan penanggulangan bencana terkait pelatihan evakuasi dan jenis peringatan. Model dibangun dengan menggunakan software Vensim. Setelah model lulus uji, dilakukan skenario perbaikan sistem dengan melihat peningkatan jumlah penduduk yang sampai di barak pengungsian. Pengujian model yang dilakukan adalah boundary adequecy test, extreme condition test dan behavior reproduction test. Dari hasil simulasi skenario perbaikan I yaitu dengan cara meningkatkan pelatihan evakuasi dan meningkatkan pengetahuan mengenai jalur evakuasi menghasilkan peningkatan jumlah penduduk yang mencapai barak pengungsian bila dibandingkan dengan kondisi awal. Skenario perbaikan II dengan memaksimalkan jenis penyebaran peringatan memberikan hasil peningkatan jumlah populasi yang menuju barak pengungsian. Skenario dengan peningkatan jumlah penduduk yang mencapai barak pengungsian tertinggi adalah skenario III yang merupakan kombinasi skenario I dan skenario II yang mana meningkatkan pelatihan evakuasi, meningkatkan pengetahuan mengenai jalur evakuasi dan memaksimalkan penyebaran jenis peringatan.
\end{abstract}

Kata Kunci: Simulasi, Evakuasi, Erupsi Merapi, System Dynamics.

\section{Pendahuluan}

Indonesia merupakan negara rawan bencana, salah satunya karena wilayah Indonesia berada di jalur vulkanik (ring of fire) yang berisiko terjadinya letusan gunung api yang dikenal dengan istilah erupsi. Bencana erupsi Merapi pada tahun 2010 menurut Badan Nasional Penanggulangan Bencana (BNPB) merupakan yang terbesar dibandingkan dengan bencana serupa dalam lima periode waktu sebelumnya. Proses evakuasi merupakan proses untuk memindahkan orang dari daerah yang terancam ke lokasi yang lebih aman (Mei et al, [16]) dan salah satu tindakan yang paling penting untuk mengurangi resiko vulkanik (Marzocchi dan Woo, [15]).

Evakuasi dalam menghadapi bahaya vulkanik memiliki satu perbedaan jika dibandingkan dengan evakuasi dari dampak bencana alam lainnya, yaitu durasi masa evakuasi tidak pasti (Gaudru, [10]). Akibatnya dapat menyebabkan kesulitan bagi pemerintah, relawan dan bahkan dapat mengakibatkan frustrasi di kalangan penduduk selama periode evakuasi. Sifat kompleks krisis vulkanik yang dapat menyebabkan kesulitan dalam perencanaan evakuasi yaitu ketika aktivitas vulkanik yang dikhawatirkan tidak terjadi, bila ada kesenjangan dalam komunikasi, dan bila ada perlawanan dari orangorang untuk meninggalkan daerah berisiko (Mei et al., 2013).

Proses evakuasi merupakan suatu proses yang kompleks (Mei et al, [16]; Pan, [17]) selain karena banyaknya pihak yang bertanggung jawab, perilaku dari manusia juga sangat mempengaruhi. Memahami perilaku manusia saat bencana, terutama dalam menanggapi peringatan evakuasi, penting dan signifikan dalam mengurangi potensi kerugian (Ahmad dan Simonovic, [1]; Hasan et al., [11]). Peringatan evakuasi akan memicu proses pengambilan keputusan untuk melakukan evakuasi. Peringatan tidak sekedar menyampaikan pesan namun merupakan proses sosial yang mencakup berbagai aktivitas berupa penyampaian peringatan dini, penyebarannya, penerimaan dan tanggapan terhadap peringatan tersebut (Mileti et al., 1975; Nigg, 1993 dalam Dash dan Gladwin, [7]). Reaksi seseorang terhadap apa yang mereka dengar bergantung pada bagaimana mereka menginterpretasikan peringatan tersebut berdasarkan 
pengalaman dan pengetahuannya, terlebih lagi pada daerah yang rawan bencana.

Perilaku evakuasi merupakan pilihan yang dibuat dan tindakan protektif yang diambil dalam keadaan darurat atau krisis (Fraser et al., [9]). Perilaku ini dipengaruhi oleh kondisi daerah bencana, konteks sosial dan budaya, tanda-tanda dari alam serta peringatan. Karakteristik individu dalam sosial demografi mempengaruhi dalam menginterpretasi peringatan, pemahaman mengenai resiko serta pengambilan keputusan dalam melakukan proses evakuasi. Hal itu didukung juga oleh Dash dan Gladwin [7] perilaku keputusan dalam proses evakuasi dipengaruhi oleh informasi mengenai peringatan, persepsi mengenai bahaya (risk perception) dan waktu evakuasi.

Dalam meningkatkan proses evakuasi, pemodelan dan simulasi dapat dilakukan untuk menambah wawasan proses evakuasi saat terjadinya bencana. Keputusan untuk melakukan evakuasi merupakan hal yang penting untuk perencanaan evakuasi dan modeling. Oleh sebab itu mengidentifikasi dan menganalisis faktor-faktor yang mempengaruhi keputusan evakuasi dibutuhkan untuk perencanaan dan operasi evakuasi yang lebih baik (Lim et al., [13]). Hal tersebut juga diperkuat oleh Quarantelli dan Russell (1977) dalam Simonovic dan Ahmad [19]mengenai kebutuhan yang harus ditingkatkan dalam proses evakuasi yakni pemahaman kita tentang sisi sosial proses manajemen darurat, pemahaman kita tentang perilaku manusia selama keadaan darurat, komunikasi antara penduduk yang terkena dampak oleh otoritas bencana dan manajemen darurat, kesiapan melalui simulasi, atau investigasi " what-if" skenario.

Pemahaman mengenai perilaku evakuasi yang melibatkan manusia dalam menanggapi bencana dan kemampuan dalam menggambarkannya pada model dinamika akan memberikan pemahaman yang lebih baik pada analsis kebijakan dalam penanggulangan bencana. Oleh sebab itu menurut Simonovic dan Ahmad [19] untuk dapat menangani karakteristik masalah simulasi evakuasi tersebut maka metode pemodelan yang dapat digunakan adalah System Dynamics (SD).

\section{Tinjauan Pustaka}

Persiapan untuk tindakan darurat harus diambil sebelum krisis. Beberapa alasan untuk persiapan awal adalah bahwa kondisi dalam suatu wilayah yang terkena dampak bencana cenderung kacau. Komunikasi sulit dan struktur komando dapat berantakan karena kegagalan logistik atau komunikasi. Perilaku manusia selama masa darurat akan sulit dikontrol dan diprediksi (Simonovic dan Ahmad, [19]).

Dalam kondisi tersebut proses evakuasi pada masa darurat merupakan hal yang paling penting. Beberapa penelitian telah dilakukan terkait dengan pentingnya proses evakuasi dalam upaya untuk mengurangi resiko bencana (Lim $\mathrm{Jr}$ et al., [14];
Marzocchi dan Woo, [15]; Dash dan Gladwin, [7]). Proses evakuasi merupakan suatu proses yang kompleks karena selain melibatkan banyak aktor (Mei et al., [16]; Lim et al., [13]; Besiou et al., [2]; Proulx, [18]), faktor perilaku dari manusia juga sangat mempengaruhi (Ilmia, [12]; Pan, [17]; Dash dan Gladwin, [7]). Seperti yang disampaikan oleh Quarantelli dan Russell (1977, dalam Simonovic dan Ahmad, [19]) mengenai kebutuhan yang harus ditingkatkan dalam proses evakuasi salah satunya yakni kesiapan melalui simulasi. Menjawab kebutuhan proses evakuasi tersebut, maka banyak penelitian yang telah dilakukan untuk mensimulasikan proses evakuasi (Wijaya, [23]; Tan, [24]; Hasan et al, [11]; Simonovic dan Ahmad, [19]; Chunmei, [6]).

\section{Proses Evakuasi dan Kajian Perilaku Manusia}

Menurut Lim Jr et al. [14] dalam upaya untuk menghindari resiko bahaya bencana, persiapan dalam proses evakuasi sangat diperlukan. Literatur review yang dilakukan membahas mengenai penelitian evakuasi dari konteks perilaku, analisis resiko dan pemodelan transportasi pada bencana banjir.

Pilihan keputusan evakuasi selama bencana terbagi dua yakni bersedia untuk dievakuasi atau tidak (tinggal di daerah beresiko). Hal tersebut dilihat sebagai suatu keputusan yang sederhana namun melibatkan perilaku yang kompleks dan faktor eksternal lainnya (Lim et al., [13]). Menurut Dash dan Gladwin [7]perilaku keputusan dalam proses evakuasi dipengaruhi oleh informasi mengenai peringatan (warning), persepsi mengenai bahaya (risk perception) dan waktu evakuasi.

Survei mengenai perilaku terhadap bencana di beberapa jenis bencana telah dilakukan untuk mengetahui bangaimana persepsi masyarakat terhadap bencana vulkanik (Bird, [3]; Dewi, [8]), perilaku manusia terhadap erupsi gunungapi (Mei et al., [16]; Ilmia, [12]), dan perilaku manusia terhadap kebakaran (Proulx, [18]).

Penelitian yang dilakukan Mei et al. [16] menganalisis evakuasi massal secara kronologis dan mendiskusikan tantangan dan kendala yang disajikan untuk manajemen bencana, serta pelajaran yang dapat membantu memandu kebijakan evakuasi untuk evakuasi vulkanik yang lebih besar.

\section{Pemodelan dan Simulasi}

Dalam meningkatkan proses evakuasi pemodelan dan simulasi dapat digunakan. Menurut Lestari et al. [22[pemodelan dan simulasi secara praktis dapat meminimalkan berbagai konsekuensi negatif serta memberikan masukan dan wawasan untuk membantu dalam pengambilan keputusan. Wijaya [23[ melakukan pengembangan sebuah model simulasi untuk evakuasi kondisi darurat dari bencana gempa bumi dengan menggunakan Agent Based Modeling. Tujuan dari penelitian Wijaya [23] yakni mengetahui waktu evakuasi 
dengan memasukkan mekanisme interaksi yang terjadi antar agent dan lingkungan dalam proses evakuasi.

Penelitian Simonovic dan Ahmad [19] membahas mengenai faktor-faktor manusia dalam pengambilan keputusan untuk melakukan evakuasi. Tujuan dari penelitian Simonovic dan Ahmad [19] yakni mensimulasikan perilaku manusia terhadap penerimaan perintah evakuasi penduduk di daerah resiko bencana, jumlah keluarga dalam proses evakuasi; dan waktu yang dibutuhkan untuk semua mengungsi ke daerah yang lebih aman. Fokus bencana pada penelitian Simonovic dan Ahmad [19] adalah pada bencana banjir dan metode yang digunakan adalah System Dynamics (SD) sehingga dapat menunjukkan hubungan timbal balik dari setiap variabel pada causal loop yang dihasilkan.

Pada bencana kebakaran Chunmei [6] juga menggunakan SD hal tersebut menurut Chunmei [6] perilaku manusia pada saat bencana dipengaruhi oleh informasi dan proses pengambilan keputusan. Tujuan dari penelitian Chunmei [6] yakni mengidentifikasi perilaku manusia yang rasional dalam kasus kebakaran atau keadaan darurat dan mengembangkan kerangka kerja untuk analisis proses perilaku pergerakan manusia dari sudut pandang sistem.

\section{Pemilihan Metode Pemodelan dan Simulasi}

Keadaan darurat pada saat bencana memiliki karakteristik ketidakpastian yang tinggi, bersifat kompleks dan melibatkan faktor manusia. Berdasarkan tinjauan pustaka dari beberapa penelitian maka beberapa metode pemodelan dan simulasi yang dapat digunakan dalam menyelesaikan masalah tersebut dan perbandingannya dapat dilihat pada Tabel 1 .

Tabel 1. Perbandingan metode pemodelan dan simulasi

\begin{tabular}{lccc}
\multicolumn{1}{c}{ Karakteristik } & $\begin{array}{c}\text { Mixed } \\
\text { Logit }\end{array}$ & $\begin{array}{c}\text { Agent } \\
\text { Based }\end{array}$ & $\begin{array}{c}\text { System } \\
\text { Dynamics }\end{array}$ \\
\hline $\begin{array}{l}\text { Hubungan timbal balik } \\
\text { dari variabel }\end{array}$ & - & $\sqrt{ }$ & $\sqrt{ }$ \\
\hline $\begin{array}{l}\text { Memodelkan perilaku } \\
\text { manusia }\end{array}$ & $\sqrt{ }$ & $\sqrt{ }$ & $\sqrt{ }$ \\
\hline $\begin{array}{l}\text { Proses pengambilan } \\
\text { keputusan kebijakan }\end{array}$ & $\sqrt{ }$ & $\sqrt{ }$ & $\sqrt{ }$ \\
\hline Pedekatan top-down & - & - & $\sqrt{ }$ \\
\hline
\end{tabular}

System Dynamics (SD) merupakan salah satu metode pemodelan dan simulasi yang mampu memahami perilaku sistem dari waktu ke waktu (Sterman, [21]). Metode ini dapat menjelaskan hubungan timbal balik dari variabel yang mempengaruhi dalam suatu sistem, yang mana digambarkan secara sederhana dan mudah dipahami dalam causal loop diagram. Pendekatan metode melihat permasalahan sebagai gambaran besar (the big picture) yang dikenal dengan istilah pendekatan top down. Selain dapat digunakan dalam menganalisis dan memodelkan berbagai sistem seperti sistem fisik, alam, kimia, biologi dan ekologi, metode ini juga dapat digunakan dalam memodelkan sistem sosial yang mana memperlihatkan perilaku dari manusia. Menurut Simonovic [20] salah satu keuntungan dari penggunaan metode ini adalah kesederhaan dalam mengaplikasikannya.

\section{Metode Penelitian}

Subyek penelitian ini adalah perilaku masyarakat sekitar Gunung Merapi saat melakukan pengambilan keputusan untuk melakukan tindakan evakuasi pada fase terjadinya bencana erupsi Merapi pada tahun 2010.

Alat bantu yang digunakan dalam penelitian ini antara lain: (1) software Vensim PLE, digunakan dalam proses pembuatan model simulasi. Software ini digunakan untuk pembuatan causal loop diagram, stock and flow diagram, serta analisis hasil simulasi. (2) Software SPSS v.20, digunakan untuk melakukan analisis statistik pada behaviour reproduction test.

Adapun tahapan penelitian yang telah dilakukan yakni (1) studi literatur, melakukan kajian terhadap penelitian-penelitian sebelumnya untuk memberi gambaran mengenai perilaku evakuasi dan tahapantahapan dalam melakukan simulasi menggunakan System Dynamic. (2) pengumpulan data, Data yang digunakan dalam penelitian ini merupakan data sekunder yang telah dilakukan oleh peneliti sebelumnya yakni Dewi (2014) dan Mei et al., [16] dalam penentuan variabel kunci yang mempengaruhi perilaku masyarakat pada bencana erupsi Merapi pada tahun 2010. Kedua penelitian tersebut melakukan survei langsung pada masyarakat di sekitar Gunung Merapi terkait dengan erupsi Merapi pada tahun 2010. (3) Problem Articulation, pada tahap ini dilakukan penentuan masalah berdasarkan tujuan penelitian. Berdasarkan tinjauan pustaka, dilakukan penentuan variabel dominan yang mempengaruhi perilaku manusia dalam pengambilan keputusan evakuasi. Pada tahap ini juga dilakukan penentuan reference modes. (4) Formulation of Dynamics Hypothesis, tahapan ini merupakan tahapan pemetaan masalah dari rumusan awal, variabel kunci, dan data lain yang tersedia. (5) Formulation of a Simulation Model, pada tahap ini formulasi dari model simulasi didefenisikan yakni kuantifikasi dari setiap variabel dengan mendefenisikan stock, flow, auxiliary dan konstanta yang selanjutnya untuk membangun stock and flow diagram. (6) Model Testing, model yang telah diformulasikan akan diuji dan dikaliberasi. (7) Policy Design and Evaluation, pada tahap ini dilakukan strategi perbaikan setelah menganalisis hasil simulasi. Penerapan strategi dilakukan dengan melakukan beberapa skenario dalam model .

\section{Hasil dan Pembahasan}

Setelah model dibangun selanjutnya dilakukan pengujian model yakni :

1. boundary adequecy test, pengujian tersebut dilakukan dengan konsultasi terhadap expert bencana erupsi kesimpulan yang diperoleh memiliki persamaan saran bahwa variabel yang mempengaruhi 
sebenarnya cukup banyak namun untuk batasan model yang dibuat bisa mewakili variabel kunci serta tidak ada perubahan variable.

2. Extreme condition test, dilakukan untuk melihat perilaku model pada situasi yang ekstrim dan untuk mengetahui apakah respon model masuk akal atau tidak. Variabel yang diamati pada uji ini adalah populasi dalam zona bahaya, pengetahuan mengenai jalur evakuasi dan keberadaan petugas penanggulangan bencana. Dari hasil pengujian diperoleh kesimpulan bahwa respon model pada ketiga variable masuk akal sesuai kondisi actual.

3. Behavior reproduction test, dilakukan dengan pengujian statistik terhadap output dari simulasi dan data aktual. Pengujian yang dilakukan adalah dengan menggunakan Wilcoxon signed-ranks test. Berdasarkan hasil pengujian dapat disimpulkan bahwa tidak ada selisih signifikan antara output model simulasi dengan data aktual pada tingkat kepercayaan 95\%. Perbandingan grafik data aktual dengan hasil simulasi dapat dilihat pada Gambar 1.

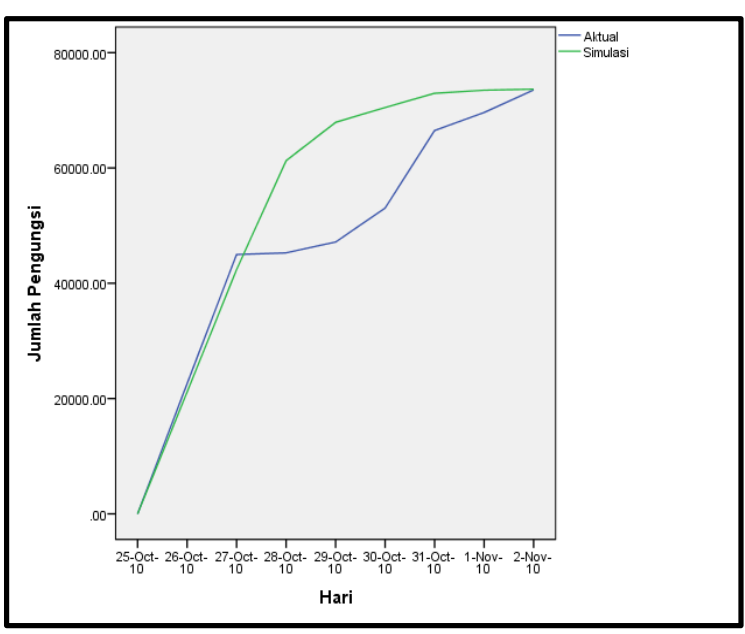

Gambar 1. Perbandingan grafik data aktual dengan hasil simulasi

\section{Perilaku Model}

Hasil dari simulasi akan menunjukkan perilaku dari sistem yang mana setiap variabel saling berhubungan dan saling mempengaruhi. Hasil simulasi dari perilaku evakuasi erupsi Merapi, ditunjukkan dengan jumlah populasi dalam zona bahaya dan jumlah populasi yang menuju barak pengungsian dapat dilihat pada Gambar 2 dan Gambar 3.

Tujuan dari model ini adalah untuk memodelkan evakuasi pada erupsi Merapi 2010. Pada Gambar 2 penurunan jumlah populasi disebabkan karena populasi yang memutuskan untuk melakukan evakuasi terus meningkat hal tersebut sesuai dengan kondisi nyata, bahwa bila bencana terjadi maka tujuan dilakukan evakuasi adalah untuk menyelamatkan populasi yang berada dalam zona bahaya ke lokasi yang lebih aman (Mei et al, [16]). Begitu sebaliknya pada Gambar 3 jumlah populasi yang menuju barak pengungsian akan terus meningkat.

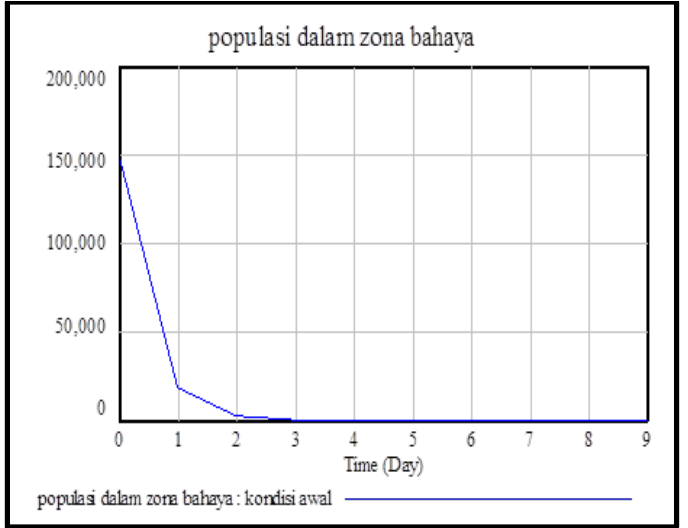

Gambar 2. Jumlah populasi dalam zona bahaya

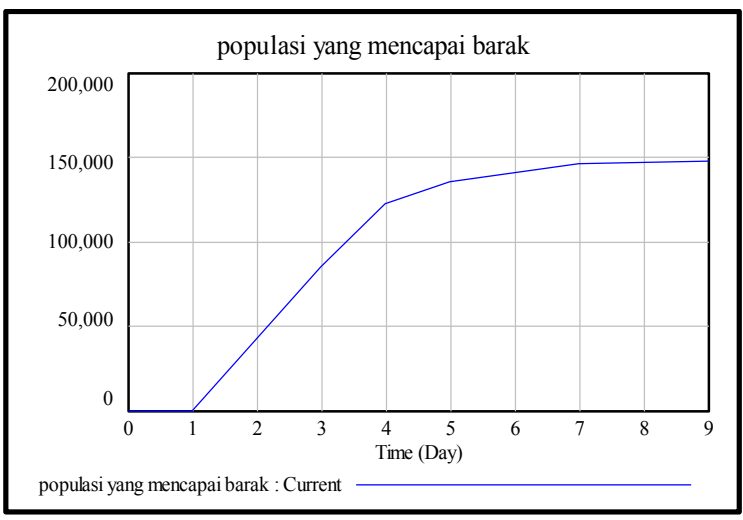

Gambar 3. Jumlah populasi yang menuju barak pengungsian

\section{Skenario Perbaikan}

Skenario perbaikan pada penelitian ini yaitu pada pengaruh pelatihan evakuasi dan jenis peringatan. Pemilihan tersebut berdasarkan program pemerintah yang dikenal dengan istilah mitigasi. Mitigasi adalah serangkaian upaya untuk mengurangi risiko bencana, baik melalui pembangunan fisik maupun penyadaran dan peningkatan kemampuan menghadapi ancaman bencana (UU No 24 Tahun 2007). Salah satu strategi kebijakan yang dilakukan dalam mitigasi adalah mengenai pentingnya pelatihan evakuasi dan peringatan dini.

Perbandingan ketiga skenario perbaikan yang telah dilakukan secara ringkas dapat dilihat pada Tabel 3.

\begin{tabular}{ccl}
\multicolumn{2}{c}{ Tabel 3. Perbandingan skenario simulasi } & \\
\hline $\begin{array}{c}\text { Nama } \\
\text { skenario }\end{array}$ & \multicolumn{1}{c}{$\begin{array}{c}\text { Penjelasan } \\
\text { skenario }\end{array}$} & Hasil simulasi \\
\hline Perbaikan I & $\begin{array}{l}\text { Meningkatkan } \\
\text { pelatihan }\end{array}$ & Jumlah populasi \\
& evakuasi dan & yang menuju \\
& bengetahuan & pengungsian \\
& mengenai jalur & semakin \\
& evakuasi & meningkat \\
\hline
\end{tabular}


Tabel 3. Perbandingan skenario simulasi

\begin{tabular}{|c|l|l|}
\hline $\begin{array}{c}\text { Nama } \\
\text { skenario }\end{array}$ & $\begin{array}{c}\text { Penjelasan } \\
\text { skenario }\end{array}$ & Hasil simulasi \\
\hline Perbaikan II & $\begin{array}{l}\text { Memaksimalkan } \\
\text { jenis penyebaran } \\
\text { peringatan }\end{array}$ & $\begin{array}{l}\text { Jumlah populasi } \\
\text { yang menuju } \\
\text { barak } \\
\text { pengungsian } \\
\text { semakin } \\
\text { meningkat }\end{array}$ \\
\hline & $\begin{array}{l}\text { Meningkatkan } \\
\text { pelatihan } \\
\text { evakuasi, } \\
\text { meningkatkan } \\
\text { Pengetahuan } \\
\text { mengenai jalur }\end{array}$ & $\begin{array}{l}\text { Jumlah populasi } \\
\text { yang menuju } \\
\text { barak } \\
\text { pengungsian } \\
\text { semakin } \\
\text { meningkat }\end{array}$ \\
& $\begin{array}{l}\text { evakuasi dan } \\
\text { memaksimalkan } \\
\text { penyebaran jenis } \\
\text { peringatan }\end{array}$ & \\
\hline
\end{tabular}

Gambar 4 menunjukkan hasil simulasi jumlah populasi yang menuju barak pengungsian, pada beberapa skenario tersebut dapat dilihat bahwa skenario yang memiliki grafik tertinggi adalah skenario III.

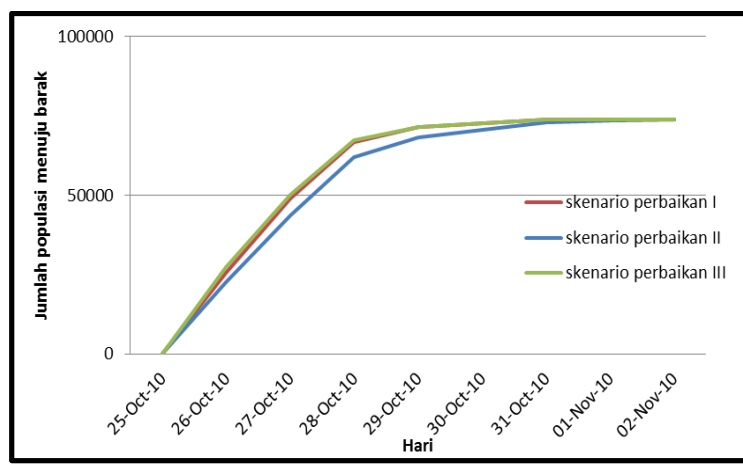

Gambar 4. Perbandingan simulasi jumlah populasi yang menuju barak pengungsian seluruh skenario

Berdasarkan skenario perbaikan yang telah dilakukan jumlah populasi yang mencapai barak pengungsian tertinggi adalah dengan meningkatkan pelatihan evakuasi, meningkatkan pengetahuan mengenai jalur evakuasi dan memaksimalkan penyebaran jenis peringatan. Hal tersebut sejalan dengan program pemerintah yang mana berdasarkan UU No 24 Tahun 2007 mengenai program mitigasi dengan tujuan mengurangi resiko bencana. Dalam modul pengurangan resiko bencana Pemerintah Kab. Sleman bentuk program dalam peningkatan pelatihan evakuasi adalah dilakukannya sosialisasi, wajib latih dan pelatihan SAR (BPBD, [4]). Pemasangan plang jalur evakuasi guna meningkatkan pengetahuan mengenai jalur evakuasi. Serta penyebaran peringatan dini menjangkau sebanyak mungkin anggota masyarakat, segera, tegas, jelas dan tidak membingungkan serta bersifat resmi atau disepakati oleh semua pihak (BPBD, [5]).

\section{Kesimpulan}

Evakuasi erupsi Gunung Merapi dengan menggunakan pendekatan System Dynamics telah berhasil dibuat dan telah lulus pengujian model. Pengujian model yang dilakukan adalah boundary adequecy test, extreme condition test dan behavior reproduction test. Kajian skenario penanggulangan bencana dalam proses evakusi terkait pelatihan dan jenis peringatan telah dilakukan. Skenario dengan peningkatan jumlah penduduk yang mencapai barak pengungsian tertinggi adalah skenario III yang merupakan kombinasi skenario I dan skenario II yang mana meningkatkan pelatihan evakuasi, meningkatkan pengetahuan mengenai jalur evakuasi dan memaksimalkan penyebaran jenis peringatan.

Penelitian mendatang dapat dikembangkan lebih luas dengan menambahkan faktor-faktor lain yang mempengaruhi seperti faktor lansia dan difable.

\section{Daftar Pustaka}

[1] Ahmad, S. dan Simonovic, S. P., Modeling Human Behavior for Evacuation Planning: A System Dynamics Approach, dalam Bridging the Gap, Proceedings of the ASCE world water and environmental resources congress, 2001, pp. 14.

[2] Besiou, M., Stapleton, O., dan Wassenhove, L. N. V, System dynamics for humanitarian operations, Journal of Humanitarian Logistics and Supply Chain Management, 2011, vol. 1, pp. 78-103.

[3] Bird, D. K., Gisladottir, G., dan DomineyHowes, D., Resident perception of volcanic hazards and evacuation procedures, Natural Hazards Earth System. Science, 2009, vol. 9, pp. 251-266.

[4] BPBD, Modul ToT Pengurangan Resiko Bencana BPBD Kab. Sleman Tahun 2012, Yogyakarta, 2012.

[5] BPBD, Dokumen Kontijensi Rehabilitasi dan Rekonstruksi Erupsi Gunung Api, Pemerintah Kab. Sleman, Yogyakarta. 2012.

[6] Chunmei, Z., A Study On Human Premovement Behavior Under Emergencies Using System Dynamics Approach (Dissertation), City University Of Hong Kong, 2007.

[7] Dash, N. dan Gladwin, h., Evacuation Decision Making and Behavioral Responses: Individual and Household, Natural Hazards Review, 2007, vol.8, pp.69-77.

[8] Dewi, R.,K., Analisis Persepsi Risiko Pada Penduduk Terhadap Bencana Gunung Merapi, Jurusan Teknik Mesin dan Industri Fakultas Teknik Universitas Gadjah Mada, Yogyakarta, 2014. 
[9] Fraser, S.A., Johnston, D.,M., dan Leonard, G., S., Intended Evacuation Behaviour in a Local Earthquake and Tsunami at Napier, New Zeland, GNS Sience Report, 2013, vol. 26.

[10] Gaudru, H., Potential Impacts of Eruptions on Volcanic Islands: Global Approach for Volcanic Risk Mitigation, 2005, retrieved from http://www.islandvulnerability.org/SVEVolcan icIslands.rtf on 26 September 2014.

[11] Hasan, S., Ukkusuri, S., Gladwin, H.,dan Murray-Tuite, P., Behavioral Model to Understand Household-Level Hurricane Evacuation Decision Making, Journal of Transportation Engineering, 2011, vol. 137, pp. 341-348.

[12] Ilmia, D. G., Kajian Perilaku Manusia Saat Bencana dengan Knowledge Engineering, Jurusan Teknik Mesin dan Industri Fakultas Teknik Universitas Gadjah Mada, Yogyakarta, 2014.

[13]Lim, Ma. B., Lim jr, H., dan Piantanakulchai, M., Factors Affecting Flood Evacuation Decision and Its Implication to Transportation Planning, Proceedings of the Eastern Asia Society for Transportation Studies, 2013, Vol.9.

[14] Lim jr, H., Lim, Ma. B., dan Piantanakulchai, M., A Review of Recent Studies on Flood Evacuation Planning, Proceedings of the Eastern Asia Society for Transportation Studies, 2013, Vol.9.

[15] Marzocchi, W., dan Woo, G., Probabilistic eruption forecasting and the call for an evacuation, Geophysical Research Letters, 2007, vol. 34 .

[16] Mei, E., W., Lavigne F., Picquout, A., de Bélizal E., Brunstein, D., Grancher, D., Sartohadi, J., Cholik, dan N., Vidal, C., Lessons learned from the 2010 evacuations at
Merapi volcano, Journal of Volcanology and Geothermal Research, 2013, no. 261, pp. 348365.

[17] Pan, Dissertation Computational Modeling of Human and Social Behaviors for Emergency Egress Analysis, Standford University, 2006.

[18] Proulx, G., Occupant Behavior and Evacuation, International Fire Protection Symposium, 2001, pp. 219-232.

[19] Simonovic, S. P. dan Ahmad, S., Computerbased Model for Flood Evacuation Emergency Planning, Natural Hazards, 2005, vol. 34, pp. 25-51.

[20] Simonovic, S.P., System Approach to Management of Disaster, John Wiley \& Sons, Inc., Canada, 2011.

[21] Sterman, J.D., Business Dynamics: Systems Thinking and Modeling for a Complex World, McGraw-Hill, USA, 2000.

[22] Lestari, F. Ismail, K. Abdul Hamid, A.B. Supriyanto, E. Sutupo, W. Simulation of Refinery-Supplier Relationship. Proceedings of the International MultiConference of Engineers and Computer Scientists, Hongkong. Vol II pp 740-744. 2016.

[23] Wijaya, I. A. H., Analisis Dinamika Evakuasi Saat Gempa Bumi Dengan Pendekatan AgentBased Modeling (Studi Kasus: Ruang Sidang 1 Jurusan Teknik Mesin dan Industri UGM), Jurusan Teknik Mesin dan Industri Fakultas Teknik Universitas Gadjah Mada, Yogyakarta, 2014.

[24] Tan, L., Hu, M., dan Lin, H., Agent-based simulation of building evacuation: combining human behavior with predictable spatial accessibility in a fire emergency, Information Sciences, 2014. 